\title{
Fatigue Behavior Comparison of Inter-Ply and Intra-Ply Hybrid Flax-Carbon Fiber Reinforced Polymer Matrix Composites
}

\author{
Md Zahirul Islam, Ali Amiri (D) and Chad A. Ulven *(D) \\ Department of Mechanical Engineering, North Dakota State University, P.O. Box 6050, Dept. 2490, \\ Fargo, ND 58108-6050, USA; mdzahirul.islam@ndsu.edu (M.Z.I.); ali.amiri@ndsu.edu (A.A.) \\ * Correspondence: Chad.Ulven@ndsu.edu
}

Citation: Islam, M.Z.; Amiri, A.;

Ulven, C.A. Fatigue Behavior

Comparison of Inter-Ply and Intra-Ply Hybrid Flax-Carbon Fiber Reinforced Polymer Matrix Composites. J. Compos. Sci. 2021, 5, 184. https:// doi.org/10.3390/jcs5070184

Academic Editors: Francesco Tornabene and Salvatore Brischetto

Received: 21 May 2021

Accepted: 9 July 2021

Published: 14 July 2021

Publisher's Note: MDPI stays neutral with regard to jurisdictional claims in published maps and institutional affiliations.

Copyright: (C) 2021 by the authors. Licensee MDPI, Basel, Switzerland. This article is an open access article distributed under the terms and conditions of the Creative Commons Attribution (CC BY) license (https:/ / creativecommons.org/licenses/by/ $4.0 /)$.

\begin{abstract}
Hybridization of natural fiber with synthetic fiber to reinforce polymer matrix composites is an effective way of increasing fatigue strength of composites with substantial amount of bio-based content. Flax is the strongest type of bast natural fiber, possessing excellent mechanical and damping properties. Fatigue properties of flax fiber hybridized with synthetic carbon fiber reinforced polymer matrix composites were studied. Fatigue properties of inter-ply hybrid flax-carbon fiber reinforced composite were compared to intra-ply hybrid flax-carbon fiber reinforced composites through tensile fatigue testing at $70 \%$ load of ultimate tensile strength and with a loading frequency of $3 \mathrm{~Hz}$. For similar amount (by mass) of flax and carbon fiber, intra-ply flax-carbon fiber hybrid reinforced composite exhibited a very large increase (>2000\%) in fatigue life compared to inter-ply flax-carbon fiber hybrid reinforced composites. Suitable hybridization can produce hybrid composites that are as strong as synthetic fiber composites while containing a high bio-based content of natural fibers.
\end{abstract}

Keywords: flax fiber; carbon fiber; hybrid composite; fatigue life; tensile strength

\section{Introduction}

Fiber reinforced polymer matrix composites are widely being used due to their desired properties such as lower weight, lower cost, and excellent corrosion resistance [1]. They have wide application in the automotive industry (car interior, door panels, dashboards, etc.) [2], aerospace, civil engineering [3], defense, sporting goods [4], shipbuilding, etc. Due to the anisotropic properties of composites, load bearing capacity of these materials can be tailored for intended application by changing the array fiber orientations [5]. There are generally two types of fibers used as reinforcement: synthetic fibers (carbon, aramid, etc.) and natural fibers (flax, hemp, etc.). Synthetic fibers have high mechanical strength but also present significant environmental impacts [6]. Using natural fibers as reinforcement in composites increases the bio-content [7], but in addition presents other benefits such as improved vibration damping properties [8]. Since natural fibers are not mechanically as strong as some synthetic fibers [9], composites using natural fibers can suffer from lower mechanical strength as compared to composites using synthetic fibers. One way to overcome this challenge is to hybridize natural fibers with synthetic fibers as a way of improving mechanical properties of composites, while reducing environmental impact [10-12]. Hybridization is generally accomplished by incorporating layers of fabric of two or more types of fibers within a common matrix material.

Hybridization between fibers with distinctly different properties helps to attain more tailored structural properties by attenuating some undesirable properties of specific fibers [13-15] while increasing other desirable properties. This approach helps to combine the best properties of different fibers to obtain unique properties [16]. Although carbon fibers have outstanding tensile properties, they have limited toughness (elongation at failure) [17]. This can be improved by hybridizing carbon fiber with plant based fibers, such as flax [18]. Moreover, it has been shown that impact resistance of carbon fiber reinforced composites can be improved when hybridized with flax fibers [19]. 
Hybrid composites reported in literature are usually manufactured by using layers of dissimilar fiber fabrics permeated with a common polymer matrix. These hybrid composites are referred to as inter-ply hybrid composites [15] and stacking sequence of those fabrics have significant influence on the properties of ensuing composites [14]. Zhang et al. showed that, although tensile strength is insensitive to the stacking sequence of glass/carbon layered hybrid composites, flexural properties change significantly with stacking sequence [20]. Randjbaran et al. showed that the ballistic impact properties of Kevlar, glass, and carbon fiber hybrid reinforced composites are influenced by the stacking sequence of fibers [21]. Furthermore, the effect of stacking sequence on the fracture toughness of glass-carbon laminated hybrid was investigated by Jung et al. [22]. Results showed that dispersed glass fibers help to increase fracture toughness of composites rather than a single layer.

Although the abovementioned hybridization discussed is based on using similar fiber fabric as one laminate (inter-ply), another type of hybridization exists by using fabrics which are co-woven using alternating thread of dissimilar fibers were also reported in literature. These types of hybrid composites are referred to as intra-ply hybrid composites [23]. Kevlar 49 and S-glass fiber woven together in weft and wrap directions were used for manufacturing hybrid composites and their mechanical properties was investigated by Valenca et al. [24]. Furthermore, glass and Kevlar fiber were also woven together using different fiber architectures and their mechanical and fracture properties were compared by Felipe et al. [25]. However, none of these studies reported the comparisons of the mechanical properties of inter-ply and intra-ply hybrid composites.

Insight into the fatigue properties of hybrid flax-carbon composites is one of the most vital for their increased use in structural applications. A few researchers have investigated fatigue behavior of inter-ply and intra-ply hybrid composites. Fatigue behavior of inter-ply glass/kenaf hybrid composites was reported by Sivakumar et al. [26] and the fatigue behavior of inter-ply glass/flax hybrid composites was reported in literature by Asgarinia et al. [27]. In addition, fatigue properties of intra-ply carbon-Kevlar hybrid composites were also reported in literature by Hashim et al. [16]. However, the comparison of fatigue life between inter-ply and intra-ply hybrid composites has not been studied in depth. Furthermore, fatigue properties of separate flax and carbon fiber reinforced polymer matrix composites has been well established in literature [28-30], while fatigue properties of intra-ply flax-carbon hybrid composites have not been reported in literature. However, the fatigue properties of inter-ply flax-carbon hybrid composites were reported by Ameur et al. [31]. Therefore, the goal of this study is to address the gap in the existing knowledge about intra-ply hybrid carbon-flax composites and compare the fatigue properties of these intra-ply flax-carbon hybrid composites with inter-ply flax-carbon hybrid composites.

\section{Materials and Methods}

\subsection{Fibers}

\subsubsection{Unidirectional Flax and Carbon Fiber}

The unidirectional carbon fiber, GA 130, was purchased from Hexcel Corporation (Stamford, Connecticut). The unidirectional carbon fiber fabric selected had an areal density of $470 \mathrm{~g} / \mathrm{m}^{2}$. A $12 \mathrm{k}$ tow (tensile modulus $=228 \mathrm{GPa}$ ) of carbon fiber was used in the warp direction having a thread count of $14 /$ inch. Weft (fill) yarn was used to hold the warp yarn and applied proprietary, having thread count $=4$ /inch.

Unidirectional flax fiber fabric was obtained from Bcomp ampliTex (Fribourg, Switzerland, Product no. 5025). The flax was grown in France and Belgium, and the non-crimp unidirectional fabric had an areal density of $280 \mathrm{~g} / \mathrm{m}^{2}$. Fiber strands had a mass of 106 tex and the fabric had a weft stitching thread (textured polyester) of $1 / \mathrm{cm}$. 


\subsubsection{Intra-Ply Hybrid (Carbon-Flax Woven Together) Fabric}

A non-crimp unidirectional intra-ply hybrid flax-carbon fabric was also purchased from Bcomp ampliTex (Fribourg, Switzerland, Product no. 5027-4). This fabric had an areal density of $175 \mathrm{~g} / \mathrm{m}^{2}$. Fabric was woven with equal mass of flax and carbon fibers (51\% flax, $49 \%$ carbon). Both flax and carbon fibers strands had an equal mass of 200 tex. The three fabric types used in this study is shown in Figure 1.

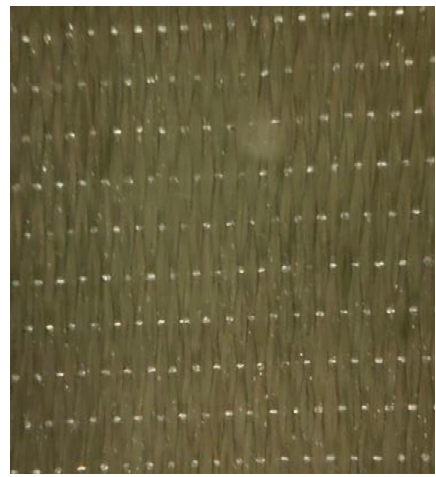

(a)

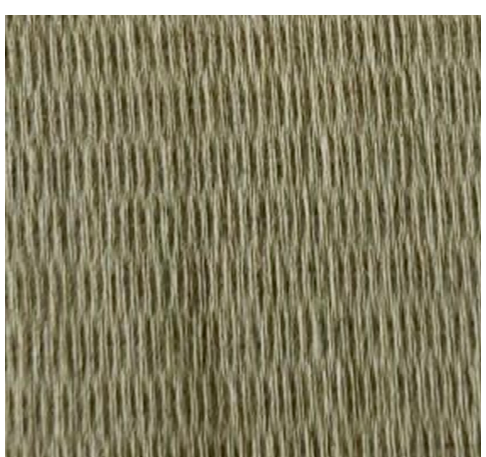

(b)

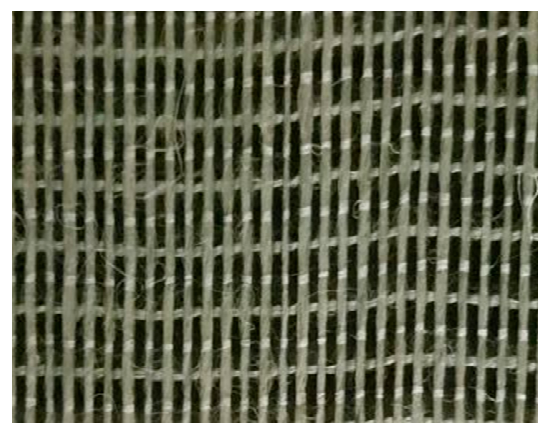

(c)

Figure 1. (a) Unidirectional carbon fiber; (b) unidirectional flax fiber; (c) flax and carbon fiber co-woven fabric for intra-ply hybrid composites.

\subsection{Matrix}

A very low viscosity infusion epoxy resin (Pro-set, INF-114, Composite Envisions, Wausau, WI, USA) was used as a matrix material. In order to crosslink the linear chain of epoxy resin, amine type cross-linker (INF-211, Composite Envisions, Wausau, WI, USA) was mixed with epoxy resin by a mass ratio (resin: cross-linker) of 3.65:1. Infusion epoxy resin mixed with amine cross-linker had viscosity of $296 \mathrm{cP}$, and density of $1138 \mathrm{~kg} / \mathrm{m}^{3}$ at $22{ }^{\circ} \mathrm{C}$.

\subsection{Manufacturing the Composites}

Composite plates of fiber reinforced composites (both inter-ply, and intra-ply) were prepared using Vacuum Assisted Resin Transfer Molding (VARTM). Table 1 describes the lay-up and properties of manufactured composites. As shown in Figure 2, layers of fabric were stacked on a glass table. Vacuum bagging was used to produce an air-tight sealing and a vacuum pump was used to draw resin inside and wet-out the fiber lay-ups. A resin distribution medium was placed over fibers to assist directional resin flow. The setup remained under vacuum for $72 \mathrm{~h}$ to ensure room temperature gelation and initial cure. Post curing of the manufactured composite plates was accomplished at $82{ }^{\circ} \mathrm{C}$ for $8 \mathrm{~h}$ using a convection oven. Inter-ply unidirectional flax-carbon hybrid composite board were prepared using seven layers of fabric and the following lay-up: $1 \mathrm{C} / 2 \mathrm{~F} / 1 \mathrm{C} / 2 \mathrm{~F} / 1 \mathrm{C}$ [C-Carbon, F-Flax]. As the areal density of the carbon fiber fabric used was about 1.7 times that of the flax fiber fabric, two flax fiber fabric layers were stacked beside one carbon fiber fabric layer. Intra-ply unidirectional hybrid composites (flax-carbon fiber woven together) was manufactured using 14 layer of hybrid fabric. 
Table 1. Properties and lay-up of produced inter-ply and intra-ply hybrid composites.

\begin{tabular}{r} 
Material-1: Inter-Ply Unidirectional Flax-Carbon Hybrid Composites \\
Fabric lay-up: $1 \mathrm{C} / 2 \mathrm{~F} / 1 \mathrm{C} / 2 \mathrm{~F} / 1 \mathrm{C}[\mathrm{C}$-carbon, F-flax], \\
Total number of layers $=7$ [three layers of carbon fiber fabric and four layers of flax fiber fabric] \\
Thickness of the produced plate $=2.8 \mathrm{~mm}$. \\
Density of the plate $(1 \mathrm{C} / 2 \mathrm{~F} / 1 \mathrm{C} / 2 \mathrm{~F} / 1 \mathrm{C})=1436 \mathrm{~kg} / \mathrm{m}^{3}$ \\
\hline Material-2: Intra-Ply Hybrid Composites (Unidirectional Flax-Carbon Fiber Woven Together) \\
\hline Fabric lay-up: 14 layers of unidirectional fabric, flax and carbon fiber woven together $(51 \%$ flax \\
and $49 \%$ carbon fiber by mass) \\
Thickness of the produced plate $=3.1 \mathrm{~mm}$ \\
Density of the plate $=1324 \mathrm{~kg} / \mathrm{m}^{3}$
\end{tabular}

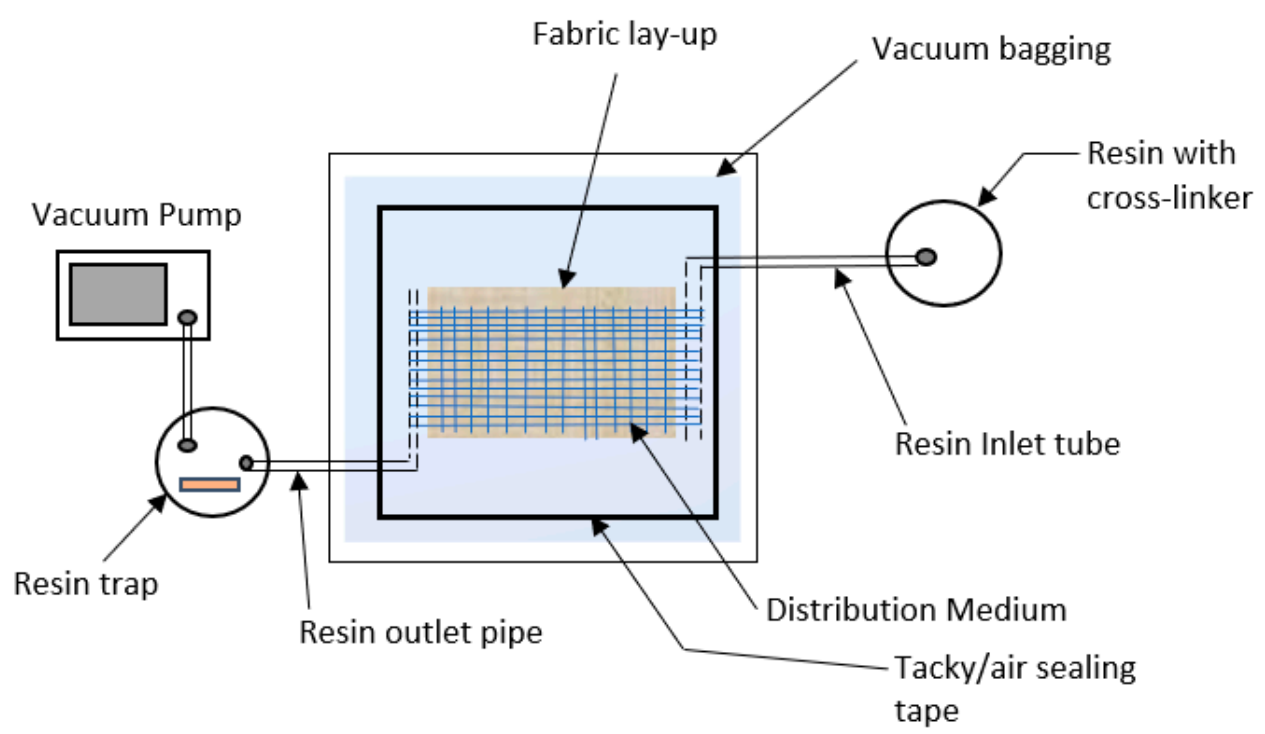

Figure 2. Schematic diagram of vacuum assisted resin transfer molding (VARTM) setup.

As shown in Table 1, both plates produced by the VARTM process resulted in almost equal density. The mass of the manufactured plates were divided by the volume of the plates to calculate the density. In order to neglect the effect of voids, volume of the plates was considered as the summation of only the volume of fibers and volume of matrix. The mass of the fibers was divided by density of fibers (density of carbon fiber $=1.76 \mathrm{~g} / \mathrm{cm}^{3}$, density of flax fiber $\left.=1.3 \mathrm{~g} / \mathrm{cm}^{3}\right)$ to calculate the volume of fibers. Similarly, the mass of matrix material was divided by the density of matrix material $\left(1.138 \mathrm{~g} / \mathrm{cm}^{3}\right)$ to calculate the volume of matrix material. The mass of matrix material was calculated by subtracting fibers mass from the mass of manufactured plate. The inter-ply hybrid composites $(1 \mathrm{C} / 2 \mathrm{~F} / 1 \mathrm{C} / 2 \mathrm{~F} / 1 \mathrm{C})$ plate had a density $=1436 \mathrm{~kg} / \mathrm{m}^{3}$, while intra-ply hybrid composites plate had a density $=1324 \mathrm{~kg} / \mathrm{m}^{3}$. The number of fiber layers was determined to ensure almost equal amount of flax and carbon fiber (by mass) in both plates. Table 2 shows the comparison of mass of flax and carbon fiber in both type manufactured plates. The overall mass difference between the two types of composites produced was less than $4 \%$. Both samples had almost equal amount of flax and carbon fiber by mass (difference was $<15 \%$ ). However, inter-ply flax-carbon hybrid composites had slightly more carbon fiber content compared to intra-ply flax-carbon hybrid composites. Moreover, both types of manufactured composites plates had comparable thickness (difference $<10 \%$ ). The inter-ply hybrid composites were slightly thinner as compared to intra-ply hybrid composites. Due to a little higher carbon fiber content and lower thickness, the inter-ply hybrid composites were expected to have a little higher tensile strength. However, they actually ended up being fairly comparable under same mechanical testing. 
Table 2. Amount of carbon and flax fiber present in inter-ply and intra-ply hybrid composites.

\begin{tabular}{ccc}
\hline & $\begin{array}{c}\text { Material-1: Inter-Ply } \\
\text { Flax-Carbon Hybrid Composites } \\
(\mathbf{1 C} / \mathbf{2 F} / \mathbf{1 C} / \mathbf{2 F} / \mathbf{1 C})\end{array}$ & $\begin{array}{c}\text { Material-2: Intra-Ply Flax-Carbon } \\
\text { Hybrid Composites } \\
\text { 14-Layer }\end{array}$ \\
\hline $\begin{array}{c}\text { Overall mass of fabric per } \\
\text { square meter, }\left(\mathrm{g} / \mathrm{m}^{2}\right)\end{array}$ & $(470 \times 3)+(280 \times 4)=2530$ & $175 \times 14=2450$ \\
\hline $\begin{array}{c}\text { Mass of carbon and flax } \\
\text { fiber separately, }\left(\mathrm{g} / \mathrm{m}^{2}\right)\end{array}$ & $\begin{array}{c}\text { Carbon fiber }=470 \times 3=1410 \\
\text { Flax fiber }=280 \times 4=1120\end{array}$ & $\begin{array}{c}\text { Carbon fiber }=2450 \times 0.49=1200 \\
\text { Flax fiber }=2450 \times 0.51=1250 \\
(51 \% \text { Carbon, } 49 \% \text { Flax })\end{array}$ \\
\hline
\end{tabular}

Furthermore, the fiber volume fraction for the inter-ply composite was $53.18 \%(27.10 \%$ carbon fiber, $26.08 \%$ flax fiber), while the fiber volume fraction for the intra-ply composites was $46.93 \%$ (19.53\% carbon fiber, $27.4 \%$ flax fiber). The traditional rule of mixtures was used to calculate the volume fraction of the composites.

\subsection{Test Specimen Fabrication}

Tensile and fatigue test specimens were cut using a ceramic wet tile saw to the dimensions of $254 \mathrm{~mm} \times 25.4 \mathrm{~mm}$ according to ASTM D3039 standard. In order to ensure proper griping and load transfer during testing, glass fiber tabs (length of $57.15 \mathrm{~mm}$ and chamfered with an angle $45^{\circ}$ ) were used on both ends of the specimens. Effective sample length was calculated by deducting tab length from the overall sample length. A servo-hydraulic MTS $250 \mathrm{kN}$ load frame was used to perform all tensile and fatigue testing.

\subsection{Tensile and Fatigue Test Parameters}

Tensile test for the inter-ply and intra-ply flax-carbon hybrid composites were conducted according to ASTM D3039 standard in displacement control mode with the crosshead displacement rate of $0.05 \mathrm{in} / \mathrm{min}$. Fatigue tests were conducted according to ASTM 3479 standard in load control mode under tension-tension sinusoidal cycle. Three samples were tested for each type. Maximum applied load during the fatigue test was $70 \%$ load of ultimate tensile strength (UTS) and the minimum applied load was $10 \%$ of the maximum applied load. Therefore, loading ratio (R) was 0.1. Loading ratio was defined as the ratio of minimum applied load to the maximum applied load during cyclic loading (fatigue test). Loading frequency was defined as the number of fatigue cycle completed per seconds. Loading frequency for all fatigue tests was set to $3 \mathrm{~Hz}$. As composite materials tend to generate heat while undergoing cyclic loading, especially in tension-tension mode, the frequency was kept low $(<5 \mathrm{~Hz})$ to reduce the effect of self-heating $[29,30,32,33]$.

\section{Results and Discussions}

\subsection{Tensile Tests}

Tensile test of inter-ply $(1 \mathrm{C} / 2 \mathrm{~F} / 1 \mathrm{C} / 2 \mathrm{~F} / 1 \mathrm{C})$ and intra-ply flax-carbon hybrid composites were carried out to define their characteristics under static loading. Two specimens were tested for each type of composites. Figure 3 shows representative tensile test curves of those composites. Mean ultimate tensile strength of inter-ply and intra-ply hybrid composites were measured as $805.26 \mathrm{MPa}$ and $765.46 \mathrm{MPa}$, respectively. As the variation in tensile strength measured between specimens was small in both cases, only two specimens were tested under quasi-static tensile test. Moreover, the overall objective of this study was to establish the fatigue life comparison of these composites. Standard deviation in the results of tensile strength (between samples) for inter-ply and intra-ply hybrid composites were $26.58 \mathrm{MPa}$ and $8.47 \mathrm{MPa}$, respectively. Inter-ply flax-carbon hybrid composites exhibited slightly higher tensile strength during tensile test. As the inter-ply hybrid composites had a lower thickness $(2.8 \mathrm{~mm})$ compared to the intra-ply composites $(3.1 \mathrm{~mm})$, it was expected that intra-ply hybrid composites may have a slightly higher tensile strength. However, difference in tensile strength (UTS) between inter-ply and intra-ply hybrid composites was still only about $5 \%$. Moreover, the tensile modulus for inter-ply and intra-ply composites were $46.61 \mathrm{GPa}$ and $36.94 \mathrm{GPa}$, respectively. 


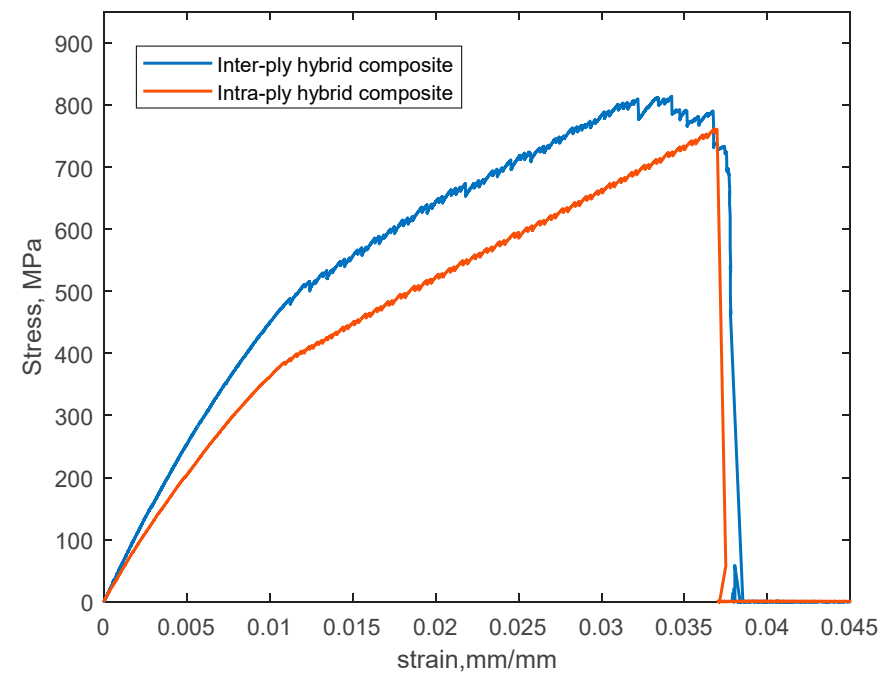

Figure 3. Tensile test curve for inter-ply and intra-ply flax-carbon hybrid composites.

As observed in Figure 3, each composite exhibited a bi-linear mechanical behavior under static loading. Inflection of bi-linear tensile test curve represents yield points. Such a bi-linear or nonlinear tensile behavior is also commonly known for the flax based natural composites [34]. The yielding stage of the curve for inter-ply composites fluctuated more than intra-ply composites. Uniformly distributed flax fiber present in the intraply composites may incorporate more damping attenuation during the yielding stage of the inter-ply composites. However, both inter-ply and intra-ply hybrid composites showed almost same strain at failure ( 3.8\%). Figure 4 shows failed inter-ply and intra-ply hybrid composites specimens during tensile testing. While significant fiber splitting was observed during the tensile failure of inter-ply flax-carbon hybrid composites, very limited to no fiber splitting was detected during the tensile failure of intra-ply hybrid composites. Carbon fibers exhibit lower strain to failure than flax fibers [10] and a continuous layer of carbon fibers are present in the outer surface of inter-ply composites. Failure of a continuous fiber layer while adjacent layer was not failed yet, may have created fiber splitting/scattering. Hence a more scattered failure mechanism was observed in the case of inter-ply configuration. While in case of intra-ply hybrid composites carbon and flax fibers are uniformly distributed throughout the specimen. No continuous layer of flax or carbon fiber is present in case of intra-ply composites. Greater damping capability of flax fiber may play a significant role in reducing scatter failure modes.

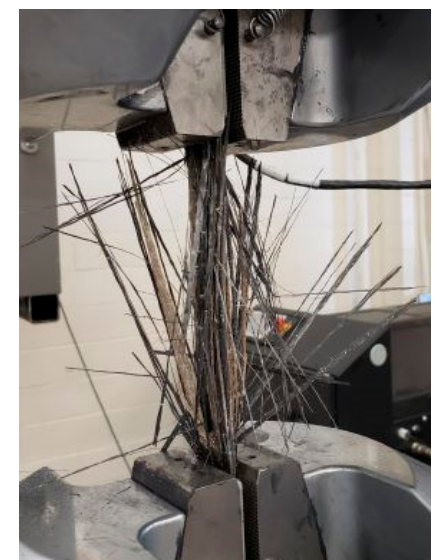

(a)

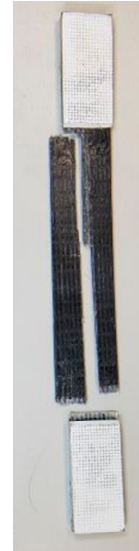

(b)

Figure 4. Failed specimen during tensile test (a) inter-ply (b) intra-ply flax-carbon hybrid composites. 


\subsection{Fatigue Tests}

Table 3 provides the results of fatigue tests (fatigue life, cycles to failure) for $70 \%$ load of UTS at loading frequency of $3 \mathrm{~Hz}$. Mean fatigue life for inter-ply and intra-ply flax carbon hybrid composites were found to be 17,034 and 365,939 cycles, respectively. Standard deviation in fatigue life for inter-ply and intra-ply hybrid composites were found to be 3707 and 137,390 cycles, respectively. Results indicate that intra-ply flax-carbon hybrid composite exhibited a much higher fatigue life as compared to inter-ply flax-carbon hybrid composites. Intra-ply hybrid composites exhibited an almost $2000 \%$ increase in fatigue life as compared to inter-ply hybrid composites. While tensile strength of the inter-ply hybrid composites and intra-ply hybrid composites were almost equal, fatigue life (cycle required to failure) was very high in case of intra-ply flax-carbon hybrid composites. Moreover, Figure 5 depicts failed specimens of the inter-ply and intra-ply hybrid composites during fatigue test. Although both inter-ply and intra-ply hybrid composites showed fiber splitting during fatigue failure, intra-ply hybrid composites exhibit much less fiber splitting during failure compared to inter-ply hybrid composites.

Table 3. Fatigue test results for inter-ply and intra-ply flax-carbon hybrid composites (three sample for each type).

\begin{tabular}{cc}
\hline $\begin{array}{c}\text { Inter-Ply Flax-Carbon Hybrid Composite } \\
\mathbf{( 1 C / 2 F / 1 C / 2 F / 1 C )}\end{array}$ & $\begin{array}{c}\text { Intra-Ply Flax-Carbon Hybrid Composite } \\
\text { (14 Layers, Flax-Carbon Co-Woven) }\end{array}$ \\
\hline 16,578 cycle to failure & 324,534 cycle to failure \\
12,739 cycle to failure & 223,057 cycle to failure \\
21,785 cycle to failure & 547,227 cycle to failure \\
(Mean $=17,034$ cycle, Standard & (Mean $=365,939$ cycle, Standard \\
deviation $=3707$ cycle) & deviation $=137,390$ cycle) \\
\hline
\end{tabular}

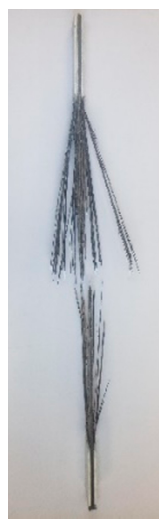

(a)

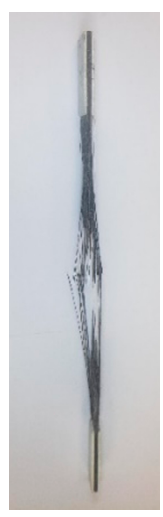

(b)

Figure 5. Failed specimens during fatigue testing of (a) inter-ply $(1 \mathrm{C} / 2 \mathrm{~F} / 1 \mathrm{C} / 2 \mathrm{~F} / 1 \mathrm{C})$, (b) intra-ply (14-layer, co-woven) hybrid composites.

Table 4 compares the currently measured fatigue life of hybrid flax-carbon fiber reinforced composites (inter-ply and intra-ply) with studies in literature using separate flax and carbon fiber reinforced composites at 70\% load of UTS with a loading ratio, $\mathrm{R}=0.1[29,30]$. Fatigue test for separate flax and carbon fiber reinforced composites reported in literature was performed at a loading frequency of $5 \mathrm{~Hz}$. In this current study, fatigue life of hybrid flax-carbon composites was measured at $3 \mathrm{~Hz}$ loading frequency. However, this slight deviation in loading frequency $(5 \mathrm{~Hz}$ to $3 \mathrm{~Hz}$ ) has not been shown in other studies to have a significant effect on fatigue life [32]. Hence, those fatigue lives were comparable with each other. 
Table 4. Comparison of fatigue life of hybrid flax-carbon fiber reinforced composite (inter-ply and intra-ply) with inbred flax-and carbon fiber reinforced composite.

\begin{tabular}{cc}
\hline Materials & $\begin{array}{c}\text { Average Fatigue Life (Cycles) } \\
\text { (At 70 } \% \text { UTS) }\end{array}$ \\
\hline Flax fiber reinforced composites & 32,407 cycles (loading frequency $=5 \mathrm{~Hz}$ ) [30] \\
\hline $\begin{array}{c}\text { Carbon fiber reinforced composites } \\
\text { (triaxially braided) }\end{array}$ & $1,000,000$ cycles (loading frequency $=5 \mathrm{~Hz}$ ) [29] \\
\hline Flax-carbon hybrid (inter-ply) & 17,034 cycles (loading frequency $=3 \mathrm{~Hz}$ ) \\
\hline Flax-Carbon hybrid (intra-ply) & $364,939$ cycles (loading frequency $=3 \mathrm{~Hz})$ \\
\hline
\end{tabular}

As seen in Table 4, inter-ply hybrid composites exhibited a fatigue life even lower than the flax fiber reinforced composites alone. This decrease can be related to variation in fiber sources and manufacturing processes. However, it can be concluded that interply hybridization of flax-carbon composites did not show any/much improvement in fatigue life due to the presence of carbon fiber. On the other hand, intra-ply hybrid flaxcarbon exhibited an increase of over $1000 \%$ in fatigue life compared to flax fiber reinforced composites. Fatigue life of carbon fiber reinforced composites $(1,000,000$ cycles) shown in Table 4 was for tri-axially braided carbon fibers. However, the difference in fatigue life between carbon fiber reinforced composites and hybrid flax-carbon composites could be significantly reduced by incorporating intra-ply configuration.

It was expected that during cyclic loading, failure of hybrid composites initiates in the fiber with lower elongation/strain-to-failure [10]. In case of flax-carbon hybrid composites, carbon fibers have lower strain to failure than flax fibers [10]. Therefore, it was expected that carbon fiber layer would fail first. Figure 6 shows the cross-section of the fiber distribution in inter-ply and intra-ply hybrid composites. In case of inter-ply hybrid composites, failure of carbon fiber would create a continuous path of crack propagation, while failure of carbon fiber would be more uniformly distributed in case of intra-ply hybrid composites. These evenly distributed micro-failures helped intra-ply hybrid flax-carbon composites to sustain a significantly prolonged number of cycles before failure under cyclic loading. Evenly distributed micro-failure impeded creating a continuous crack propagation path for failure. Therefore, unidirectional intra-ply hybrid flax-carbon/epoxy composites exhibited a very high positive hybridizing effect under cyclic loading. The verification of this hypothesis with in-situ SEM micrographs is potential future research to better understand the failure mechanism of these composites in depth.

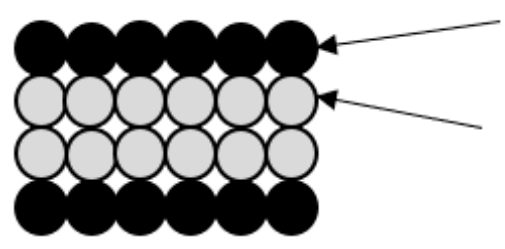

(a)
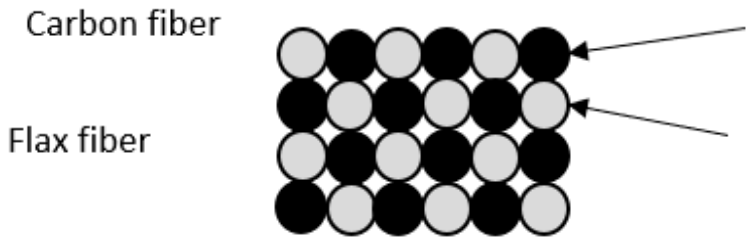

(b)

Figure 6. Schematic diagram of cross-section of fibers of (a) inter-ply hybrid composites, (b) Intra-ply hybrid composites.

Moreover, higher damping properties of flax fiber [14] may have a significant impact on increasing the dynamic/fatigue behavior of intra-ply hybrid flax-carbon composites. However, flax fibers were not able to reveal the positive effect of their improved damping characteristics in case of inter-ply configuration. Therefore, distribution of flax fiber within the hybrid composites also played a vital role in revealing the effect their improved damping characteristics during dynamic/fatigue loading.

Figure 7 provides the hysteresis loop for fatigue tests of inter-ply and intra-ply hybrid composites. For inter-ply hybrid composites, as seen in Figure 7a, the total fatigue life of 
showcased specimen was 12,739 cycles. Hysteresis loops were provided at the beginning of fatigue test (after around 50 cycles), 30\% fatigue life (after around 3800 cycles), $70 \%$ fatigue life (after around 8900 cycles), and just before the failure of the specimen. On the other side, for intra-ply hybrid composites, as seen in Figure $7 \mathrm{~b}$, the showcased specimen had a fatigue life of 547,227 cycles. Exhibited hysteresis loops were for initial fatigue cycles (after around 50 cycles), 30\% fatigue life (after around 164,000 cycles), 70\% fatigue life (after around 383,000 cycles), and just before the failure of the specimen. Area under the hysteresis loop represents the dissipated energy per fatigue cycle [30]. From Figure 7 it is clear that, hysteresis loops of intra-ply composites were narrower compared to inter-ply ones. Since the area under the hysteresis loop represents the dissipated energy per fatigue cycle [30], intra-ply composites had dissipated less energy compare to their inter-ply counterparts. Furthermore, a shift of the lower portion of hysteresis loop on load-displacement curves, denoted by 'a' on Figure 7, represents plastic deformation due to repetitive cyclic loading and/or creep due constant load component of tension-tension fatigue loading [35]. As constant load component of tension-tension fatigue loading was small (>10\% UTS), creep deformation could be neglected. Hence, ' $a$ ', as seen in Figure 7, mainly represents the plastic deformation during cyclic loading. As the thermosetting matrix (epoxy) was usually brittle and had a viscoelastic behavior, plastic or anelastic deformation was due mainly to the fibers (flax and carbon) behavior during the fatigue test.

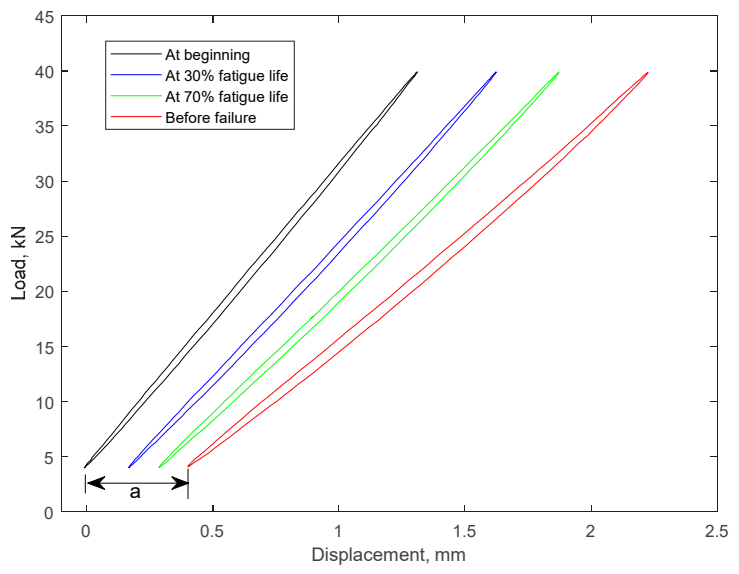

(a)

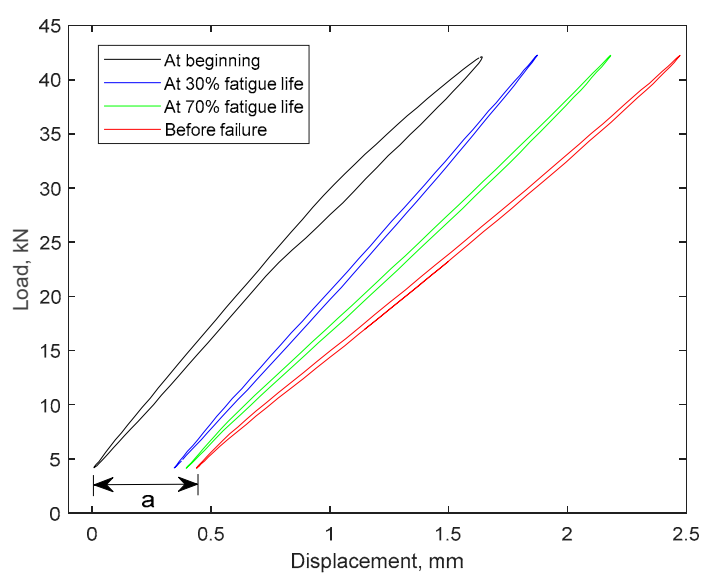

(b)

Figure 7. Hysteresis loop during the fatigue test at the beginning, 30\% fatigue life, $70 \%$ fatigue life and before failure for (a) inter-ply (b) intra-ply hybrid composites.

Figure 7 also shows that the plastic deformation before failure, ' $a$ ', was almost the same for both inter-ply and intra-ply hybrid composites. Although total plastic deformation/elongation before failure was almost same for both inter-ply and intra-ply hybrid composites, intra-ply composites exhibited a tremendous increase (almost 2000\%, as shown in Table 4) in fatigue life compared to inter-ply composites. Moreover, the slope of the hysteresis loop represents the stiffness of the materials [36]. Figure 8 showed the distribution/change of stiffness over the fatigue life for both inter-ply and intra-ply hybrid composites. Stiffness was calculated by calculating the slope of the straight line passing through the hysteresis loop generated during cyclic loading. Both inter-ply and intra-ply hybrid composite exhibited a similar level of decrease in stiffness before failure (around $30 \%$ ). Compared to inter-ply hybrid composites, intra-ply hybrid composites showed a more uniform decrease in stiffness over the entire fatigue life. Separate flax fiber reinforced composites showed around 5\% increase in stiffness before failure due to cyclic loading [37], and separate carbon fiber reinforced composites showed around 50\% decrease in stiffness before failure due to cyclic loading [38]. Therefore, it was reasonable for hybrid flax-carbon composites to have around 30\% decrease in stiffness before failure under cyclic loading. 


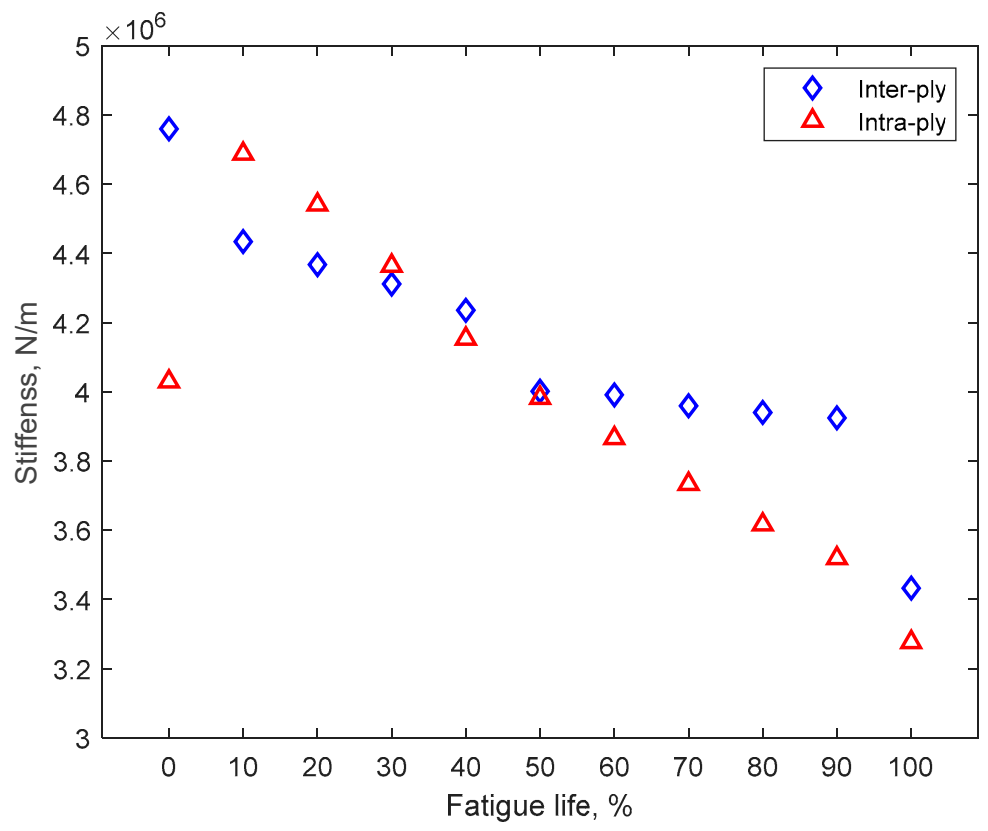

Figure 8. Stiffness distribution for inter-ply and intra-ply hybrid composites over the fatigue life.

\section{Conclusions}

Inter-ply and intra-ply flax-carbon hybrid composites were prepared for tensile and fatigue test. Each specimen consisted of almost equal amount of flax and carbon fiber by mass. Both inter-ply and intra-ply hybrid composite showed almost equal strength under tensile test. However, intra-ply flax-carbon hybrid composite exhibited more than a $2000 \%$ increase in fatigue life compared to inter-ply flax-carbon hybrid composites. Higher damping properties of flax fiber may play a significant role in improving the fatigue characteristics of intra-ply hybrid composites. Uniformly distributed flax fiber (intra-ply configuration) was also required for the activation of damping properties due to flax fiber, under cyclic loading. In case of inter-ply configuration, failure of carbon fiber (lower stain to failure) may have created a preferred continuous path of crack propagation. Due to better load transfer capability and uniformly distributed failure, intra-ply composite showed higher fatigue life, while both inter-ply and intra-ply composite exhibited similar amount of plastic deformation and stiffness degradation before failure. In addition to an increase bio-based content, intra-ply hybridization of natural fiber with synthetic fiber can create composites which are reliable under both static and dynamic loading. This study considered an inter-ply stacking sequence as follows: $1 \mathrm{C} / 2 \mathrm{~F} / 1 \mathrm{C} / 2 \mathrm{~F} / 1 \mathrm{C}$, however, a stacking sequence like: $1 \mathrm{~F} / 1 \mathrm{C} / 1 \mathrm{~F} / 1 \mathrm{C} / 1 \mathrm{~F} / 1 \mathrm{C} / 1 \mathrm{~F}$ can be a potential topic for future research.

Author Contributions: Conceptualization, C.A.U. and M.Z.I.; methodology, C.A.U. and M.Z.I.; validation, C.A.U., A.A. and M.Z.I.; formal analysis, M.Z.I.; investigation, M.Z.I.; resources, C.A.U.; data curation, M.Z.I.; writing—original draft preparation, M.Z.I.; writing-review and editing, C.A.U. and A.A.; supervision, C.A.U. and A.A.; project administration, C.A.U.; funding acquisition, C.A.U. All authors have read and agreed to the published version of the manuscript.

Funding: This work was funded by the NSF ND EPSCoR [Award \#IIA-1355466].

Conflicts of Interest: The authors declare no conflict of interest.

\section{References}

1. Kessler, M.R. Polymer matrix composites: A perspective for a special issue of polymer reviews. Polym. Rev. 2012, 52, 229-233. [CrossRef]

2. González, E.; González, E.V.; Maimí, P.; De Aja, J.S.; Cruz, P.; Camanho, P.P. Effects of interply hybridization on the damage resistance and tolerance of composite laminates. Compos. Struct. 2014, 108, 319-331. [CrossRef] 
3. Venkateshwaran, N.; Elayaperumal, A.; Sathiya, G. Prediction of tensile properties of hybrid-natural fiber composites. Compos. Part B Eng. 2012, 43, 793-796. [CrossRef]

4. Amiri, A.; Krosbakken, T.; Schoen, W.; Theisen, D.; Ulven, C.A. Design and manufacturing of a hybrid flax/carbon fiber composite bicycle frame. Proc. Inst. Mech. Eng. Part P J. Sports Eng. Technol. 2018, 232, 28-38. [CrossRef]

5. Haneefa, A.; Bindu, P.; Aravind, I.; Thomas, S. Studies on tensile and flexural properties of short banana/glass hybrid fiber reinforced polystyrene composites. J. Compos. Mater. 2008, 42, 1471-1489. [CrossRef]

6. Dris, R.; Gasperi, J.; Saad, M.; Mirande, C.; Tassin, B. Synthetic fibers in atmospheric fallout: A source of microplastics in environment. Mar. Pollut. Bull. 2016, 104, 290-293. [CrossRef]

7. Cheung, H.-Y.; Ho, M.-P.; Lau, K.-T.; Cardona, F.; Hui, D. Natural fibre-reinforced composites for bioengineering and environmental engineering applications. Compos. Part B Eng. 2009, 40, 655-663. [CrossRef]

8. Sargianis, J.J.; Kim, H.-I.; Andres, E.; Suhr, J. Sound and vibration damping characteristics in natural material based sandwich composites. Compos. Struct. 2013, 96, 538-544. [CrossRef]

9. Dittenber, D.B.; GangaRao, H.V. Critical review of recent publications on use of natural composites in infrastructure. Compos. Part A Appl. Sci. Manuf. 2012, 43, 1419-1429. [CrossRef]

10. Kureemun, U.; Ravandi, M.; Tran, L.Q.N.; Teo, W.; Tay, T.; Lee, H. Effects of hybridization and hybrid fibre dispersion on the mechanical properties of woven flax-carbon epoxy at low carbon fibre volume fractions. Compos. Part B Eng. 2018, 134, 28-38. [CrossRef]

11. Karahan, M.; Karahan, N. Investigation of the tensile properties of natural and natural/synthetic hybrid fiber woven fabric composites. J. Reinf. Plast. Compos. 2015, 34, 795-806. [CrossRef]

12. Shah, N.; Fehrenbach, J.; Ulven, C.A. Hybridization of Hemp Fiber and Recycled-Carbon Fiber in Polypropylene Composites. Sustainability 2019, 11, 3163. [CrossRef]

13. Nisini, E.; Santulli, C.; Liverani, A. Mechanical and impact characterization of hybrid composite laminates with carbon, basalt and flax fibres. Compos. Part B Eng. 2017, 127, 92-99. [CrossRef]

14. Flynn, J.; Amiri, A.; Ulven, C. Hybridized carbon and flax fiber composites for tailored performance. Mater. Des. 2016, 102, 21-29. [CrossRef]

15. Dehkordi, M.T.; Nosraty, H.; Shokrieh, M.M.; Minak, G.; Ghelli, D. Low velocity impact properties of intra-ply hybrid composites based on basalt and nylon woven fabrics. Mater. Des. 2010, 31, 3835-3844. [CrossRef]

16. Hashim, N.; Majid, D.L.A.; Mahdi, E.-S.; Zahari, R.; Yidris, N. Effect of fiber loading directions on the low cycle fatigue of intraply carbon-Kevlar reinforced epoxy hybrid composites. Compos. Struct. 2019, 212, 476-483. [CrossRef]

17. Chung, D.D. Carbon Fiber Composites; Elsevier: Amsterdam, The Netherlands, 1994.

18. Dhakal, H.; Zhang, Z.; Guthrie, R.; MacMullen, J.; Bennett, N. Development of flax/carbon fibre hybrid composites for enhanced properties. Carbohydr. Polym. 2013, 96, 1-8. [CrossRef] [PubMed]

19. Sarasini, F.; Tirillò, J.; D’Altilia, S.; Valente, T.; Santulli, C.; Touchard, F.; Chocinski-Arnault, L.; Mellier, D.; Lampani, L.; Gaudenzi, P. Damage tolerance of carbon/flax hybrid composites subjected to low velocity impact. Compos. Part B Eng. 2016, 91, 144-153. [CrossRef]

20. Zhang, J.; Chaisombat, K.; He, S.; Wang, C.H. Hybrid composite laminates reinforced with glass/carbon woven fabrics for lightweight load bearing structures. Mater. Des. 2012, 36, 75-80. [CrossRef]

21. Randjbaran, E.; Zahari, R.; Jalil, A.; Aswan, N.; Majid, A.A.; Laila, D. Hybrid composite laminates reinforced with kevlar/carbon/glass woven fabrics for ballistic impact testing. Sci. World J. 2014, 2014, 413753.

22. Jung, H.; Kim, Y. Mode I fracture toughness of carbon-glass/epoxy interply hybrid composites. J. Mech. Sci. Technol. 2015, 29, 1955-1962. [CrossRef]

23. Fariborz, S.; Yang, C.; Harlow, D. The Tensile Behavior of Intraply Hybrid Composites I: Model and Simulation. J. Compos. Mater. 1985, 19, 334-354. [CrossRef]

24. Valença, S.L.; Griza, S.; De Oliveira, V.G.; Sussuchi, E.M.; Cunha, F. Evaluation of the mechanical behavior of epoxy composite reinforced with Kevlar plain fabric and glass/Kevlar hybrid fabric. Compos. Part B Eng. 2015, 70, 1-8. [CrossRef]

25. Felipe, R.C.T.d.S.; Felipe, R.N.B.; Batista, A.C.d.M.C.; Aquino, E.M.F. Polymer composites reinforced with hybrid fiber fabrics. Mater. Res. 2017, 20, 555-567. [CrossRef]

26. Sivakumar, D.; Ng, L.; Lau, S.; Lim, K. Fatigue life behaviour of glass/kenaf woven-ply polymer hybrid biocomposites. J. Polym. Environ. 2018, 26, 499-507. [CrossRef]

27. Asgarinia, S.; Viriyasuthee, C.; Phillips, S.; Dube, M.; Baets, J.; Van Vuure, A.; Verpoest, I.; Lessard, L. Tension-tension fatigue behaviour of woven flax/epoxy composites. J. Reinf. Plast. Compos. 2015, 34, 857-867. [CrossRef]

28. El Sawi, I.; Fawaz, Z.; Zitoune, R.; Bougherara, H. An investigation of the damage mechanisms and fatigue life diagrams of flax fiber-reinforced polymer laminates. J. Mater. Sci. 2014, 49, 2338-2346. [CrossRef]

29. Montesano, J.; Fawaz, Z.; Bougherara, H. Use of infrared thermography to investigate the fatigue behavior of a carbon fiber reinforced polymer composite. Compos. Struct. 2013, 97, 76-83. [CrossRef]

30. Islam, M.Z.; Ulven, C.A. A thermographic and energy based approach to define high cycle fatigue strength of flax fiber reinforced thermoset composites. Compos. Sci. Technol. 2020, 196, 108233. [CrossRef]

31. Ben Ameur, M.; El Mahi, A.; Rebiere, J.-L.; Beyaoui, M.; Abdennadher, M.; Haddar, M. Experimental fatigue behavior of carbon/flax hybrid composites under tensile loading. J. Compos. Mater. 2021, 55, 581-596. [CrossRef] 
32. Jeannin, T.; Gabrion, X.; Ramasso, E.; Placet, V. About the fatigue endurance of unidirectional flax-epoxy composite laminates. Compos. Part B Eng. 2019, 165, 690-701. [CrossRef]

33. Islam, M.Z.; Ulven, C.A. Influence of loading frequency on thermal and micro-mechanical damage during fatigue of flax fiber reinforced composites. In Proceedings of the International Manufacturing Science and Engineering Conference, Virtual, Online, 3 September 2020; American Society of Mechanical Engineers (ASME): New York, NY, USA, 2020; p. V001T02A002. [CrossRef]

34. Derbali, I.; Terekhina, S.; Guillaumat, L.; Ouagne, P. Rapid manufacturing of woven comingled flax/polypropylene composite structures. Int. J. Mater. Form. 2019, 12, 927-942. [CrossRef]

35. Ueki, Y.; Lilholt, H.; Madsen, B. Fatigue behaviour of uni-directional flax fibre/epoxy composites. In Proceedings of the 20th International Conference on Composite Materials (ICCM20), ICCM20 Secretariat, Copenhagen, Danemark, $19-24$ July 2015.

36. Zhao, X.; Wang, X.; Wu, Z.; Keller, T.; Vassilopoulos, A. Temperature effect on fatigue behavior of basalt fiberreinforced polymer composites. Polym. Compos. 2019, 40, 2273-2283. [CrossRef]

37. Liang, S.; Gning, P.; Guillaumat, L. A comparative study of fatigue behaviour of flax/epoxy and glass/epoxy composites. Compos. Sci. Technol. 2012, 72, 535-543. [CrossRef]

38. Tate, J.S.; Kelkar, A.D. Stiffness degradation model for biaxial braided composites under fatigue loading. Compos. Part B Eng. 2008, 39, 548-555. [CrossRef] 